\title{
PRACTICE AND PROCEDURE BEFORE THE ALBERTA OIL AND GAS CONSERVATION BOARD AND THE ALBERTA GAS UTILITIES BOARD PURSUANT TO THE OIL AND GAS CONSERVATION ACT, THE GAS RESOURCES PRESERVATION ACT AND THE GAS UTILITIES ACT*
}

This article discusses the constitution, jurisdiction, practice and procedure of the Alberta Oil and Gas Conservation Board pursuant to the provisions of the Oil and Gas Conservation Act. The article considers the duties and functions of the Oil and Gas Conservation Board in hearing an application to remove gas from the Province pursuant to the provisions of the Gas Resources Preservation Act and describes the procedure used by the Board to determine whether there is a supply of gas that is in excess of the needs of Alberta and therefore available for export. The article concludes with an analysis of the role of the Gas Utilities Board in protecting the public interest of Albertans in the Province's supply of gas.

\section{A. THE OIL AND GAS CONSERVATION ACT}

\section{Organization and Constitution of the Board}

The Alberta Oil and Gas Conservation Board consists of three members, one of whom is the Chairman. Each of the members is elected for a term of five years. ${ }^{2}$ A member is to have no pecuniary interest in any oil and gas property other than shares of a corporation dealt in on a recognized stock exchange. ${ }^{8}$ In the absence of one of the members of the Board the two remaining members constitute a quorum and may continue with the business of the hearing."

While the head office of the Conservation Board is in Calgary, a meeting may be held at any place which the Chairman deems proper. ${ }^{5}$ The Chairman is considered the executive officer of the Board and has full power to act for the Board, and the Chairman or Deputy Chairman shall sign all orders of the Conservation Board. If the Chairman is absent, the Deputy Chairman can exercise all the powers of the Chairman, and if he is absent, a member of the Board has the power of the Deputy Chairman. ${ }^{\circ}$ Any order or certified copy thereof signed by the Chairman, Deputy Chairman or a member of the Board is admissible in evidence to prove the contents thereof without proof of the signatures.' In any hearing the Board may appoint a secretary, solicitor or such other employee as may be necessary. It may also obtain services of engineers, accountants, legal counsel, such technical or professional persons as may be required for the transaction of the current business before the Board, as well as one or more experts in respect of any matter in question irrespective of whether he is a member of the Board or not. ${ }^{8}$

The Board has exclusive jurisdiction with respect to any examination, inquiry or hearing pursuant to matters arising under the Oil and Gas

- This paper was prepared through the combined efforts of D. W. MAcFARLANE, Assistant General Counsel, and D. A. MAcWILLIAM, Solicitor. both of Mobil Oll Canada, Ltd.. Calgary: R. C. MUIR, and J. R. DUNNET, Solicitors, both of Gulf Oil Canada Limited, Calgary; W. H. DALGLEISH, Solicitor, Shell Canada Limited, Calgary: J. G. MAGNUS, Canada Division Attorney, Amerada Petroleum Corporation, Calgary. 1 S.A. 1957, c. 63 .

2 S. 7 .

8 S. 8.
1 S. $12(3)$

4 S. 12

6 S. 13.

7 S. 14.

B S. 16 
Conservation $\mathrm{Act}^{\mathrm{9}}$ and decisions of the Board are final except where otherwise provided by sections 118 and 119 . Subject to section 119, no Board decision or proceeding may be restrained, prohibited or removed by any court. ${ }^{10}$ Sections 104 and 105 give the Board the right to inquire into any matters of its own initiative and require that it do so upon the instigation of the Lieutenant Governor in Council. The Board is not bound by any legal rules of evidence in any of its hearings and is empowered to make rulings governing practice and procedure in its hearings provided they are not inconsistent with the express provisions of the Act itself. ${ }^{11}$ The Board is granted the right to make an order effective upon the happening of some future contingency or to limit the duration of its effect or make it conditional as it sees fit. ${ }^{12}$

An application may be heard before the Board itself or before one of its examiners, ${ }^{13}$ but where the investigation is being carried on by an examiner, the applicant or intervenor has the right to apply to have the matter heard before the Board itself. The examiner must then adjourn the hearing, inquiry or investigation and await the Board's decision as to whether the matter in consideration should be heard before the entire Board, in which event the proceedings before the examiner or examiners are of no effect. On the other hand, if the Board refuses the investigation, the examiner or examiners, as the case may be, will continue with the hearing. ${ }^{14}$

The Board, examiner, investigator, or as the case may be, is given the same powers to gather evidence and carry out the hearing as is a commissioner appointed under the Public Inquiries Act.15 No one is excused from testifying or producing books or documents of whatever kind which are relevant to the hearing for the Board's perusal if so ordered by the Board. ${ }^{10}$ The fact that such testimony or production might tend to incriminate him does not excuse him, but if he objects to answering questions or producing any documentary evidence on the ground of possible incrimination the Board shall give him the protection afforded by section 5 of the Canada Evidence Act and by section 8 of the Alberta Evidence Act." If any witness refuses to attend upon being served notice to attend by the Board, the Board may apply to a judge for a bench warrant requiring the attendance of such witness before the Board, and should any witness refuse to give evidence regarding any matter on which he is questioned, he may, upon application by the Board, be committed for contempt. ${ }^{18}$

\section{Procedure at Board Hearing}

As a general rule proceedings before the Board are quite informal. The Board has not been in the habit of requiring strict compliance with the rules of evidence applicable to proceedings in Court. However, those who have practiced before the Board will realize that the Board does attempt to follow the general principles applied in judicial proceed- 
ings in that they will not, except in special circumstances, permit the admission of new evidence upon cross-examination. Similarly, the applicant is permitted to summarize his case to the Board at the close of the presentation of evidence and cross-examination. The regulations provide that no evidence, direct or indirect, shall be received unless it relates to the establishment of facts alleged in the application or the submission of a person giving evidence or evidence adduced on crossexamination and no argument received unless it relates to evidence before the Board. ${ }^{19}$ Whereas the Board, its staff or the examiners may examine any witness he may not be cross-examined except by the applicant or an intervenor. ${ }^{20}$

The regulations set out the items which an application under the various sections of the Act must contain. ${ }^{21}$ Some of these are quite detailed, and it would appear from a very technical reading of the regulations that if certain applications before the Board do not contain the information set forth the application may not validly be before the Board. ${ }^{22}$ It would appear that the simplest and most straight forward manner of making an application under Part XIV of the Regulations, would be to follow the respective regulation point by point and to set forth the information required. Regulation 1605 , sets forth the principles to follow with respect to the form of the application. ${ }^{23}$ The procedures are basically common sense procedures which would be followed in an application before a judicial body. The applicant is required to file with the Board seven copies of the application and any particulars in support thereof. ${ }^{24}$. The Board or the examiners, as the case may be, may direct that Part XVI of the Regulations, the Rules of Practice, shall not apply to a particular hearing. ${ }^{25}$

Part XVI of the regulations also sets forth the procedure for notice by the Board and requires among other things that the Board publish notice of the hearing within twenty-one days of the completion of the

10 See Regs. 1619 and 1620. Note that Reg. 1621 makes an exception with respect to a statement or submission by the Deputy Minister of Mines and Minerals.

20 Reg. 1620.

21 See Part XIV of the Regulations.

22 See for example Regs. 1400 and 1401 which require that the application shall include certain information, whereas Reg. 1402 provides certain information shall be included where avallable, whereas other regulations provide that certain information is to be included "where applicable." Obviously the extent of the applicability or availability will be somewhat discretionary in that it will, at least in part. be related to the applicant's assessment of the reliability of such information as is available.

23 Reg. 1605 provides that:

(a) be signed or executed by the applicant or the solicitor or agent for the appli(a) be signed or executed by the app

(b) cant, and

(ii) the order, permit or approval applied for, and

(ii) the provision of the Act or regulations under which the application is made,

(iv) the information or particulars required by the Act or regulations to be filed in support of the application, and

(v) the reasons why the applicant belleves the Board should grant the application, and

(c) be divided into consecutively numbered paragraphs each of which shall be confined as nearly as may be to a separate and distinct part of the application, and

(d) be endorsed with the name and address of the applicant or applicant's solicitor or agent to whom communications may be sent.

24 Reg. 1603.

25 Reg. 1602. The Rules of Practice contained in Part XVI of the Regulations are made pursuant to the provisions of section 106 of the Oil and Gas Conservation Act and section 16 of the Gas Resources Preservation Act. Presumably where the Board or an examiner directs that Part XVI is not applicable, or where the matter is not speclfically covered by the provisions of Part XVI it may make such further regulations governing that particular hearing or the particular aspect thereof in question as it deems desirable. 
application. ${ }^{26}$ The regulations provide further for the submission of certain materials by intervenors who are either requesting a variation of the order requested by the applicant or are flatly opposing the applicant's application. ${ }^{2 i}$ If the Board had intended to dispose of the application without a hearing, it may, upon notice of objection, either set the application down for hearing, or if it considers the objection of insufficient merit, dispose of the application as originally proposed in the notice. ${ }^{28}$ If the hearing is one of a contentious matter the Board must give ten days' notice to the interested parties. ${ }^{29}$

\section{B. THE GAS RESOURCES PRESERVATION ACT ${ }^{30}$}

In November, 1948, the Lieutenant Governor in Council of the Province of Alberta, constituted a Commission under the chairmanship of Mr. R. J. Dinning to conduct an inquiry:

(1) to investigate the existing and proven reserves of natural gas in the Province;

(2) to enquire into and estimate the potential reserves of natural gas in the Province;

(3) to inquire into the present domestic, commercial and industrial consumption of natural gas in the Province;

(4) to estimate the future requirements of natural gas for domestic, commercial and industrial purposes in the Province;

(5) to make such further enquiries into the situation surrounding the use of natural gas in the Province as the Commission may deem necessary, having in mind the best interests of the people in the Province. ${ }^{31}$

Following the hearings before the Commission, at which briefs were presented by every facet of the industry, as well as from muncipalities and representatives of the Provincial Government, the Commission submitted its report on March 8, 1949. ${ }^{32}$ The report advocated that Provincial requirements should have prior claim on supplies of gas within Alberta, and that second priority should be accorded to the requirements of other Canadian consumers, in preference to areas outside Canada. ${ }^{33}$

As a result of the Commission's recommendation, The Gas Resources Preservation Act was passed in 1949. ${ }^{34}$ There were numerous revisions to the Act and in 1956 the present Act was passed. The present Act was amended in 1960, 1963 and $1966 .^{35}$ The expressed purpose of the Act is:

to effect the preservation and conservation of the oil and gas resources of the

Province and to provide for their effective ultilization having regard to the present and future needs of persons within the Province. ${ }^{36}$

When a producer of gas or propane in Alberta proposes to export such product from the Province, the producer must make an application to the Oil and Gas Conservation Board for a permit authorizing the removal of such product. The same requirement applies to a person who, in the opinion of the Board, appears to have entered into an arrangement to purchase gas or propane or who has an exclusive option

20 Reg. 1608.

27 Regs. 1610 to 1612 .

28 Reg. 1615 and s. 105 .

20 Reg. 1608 (2) (b) and s. 106 (s).

30 S.A. 1956, c. 19.

31 Commission, dated the 2nd day of November, 1948, appointing Robert J. Dinning, of the City of Calgary, Andrew Stewart, of the City of Edmonton, and Roy C. Marler, of the Hamlet of Bremner, as Commissioners to conduct the said inquiry

32 Report of the Natural Gas Commission, Queen's Printer, Edmonton, Alberta, March 8 , 1949 .

33 Id., at 122

34 S.A. 1949 (2nd Sess.), c. 2.

85 S.A. 1960, c. 63; S.A. 1963, c. 22; S.A. 1966, c. 34.

36 Supra, n. 30, s. 3. 
to purchase same or who, in the opinion of the Board, appears to have made an arrangement with the owner of gas or propane produced in Alberta to transport such product outside the Province, and in either event, proposes to remove the product from the Province. ${ }^{3 i}$

After receipt of the application and whatever material the Board may require, the Board must hold a public hearing. ${ }^{3 \times}$ Even if the Board approves the application, after taking into consideration, inter alia, the present and future needs of persons in Alberta and the established reserves and trends in growth and discovery of reserves of gas and propane in Alberta so as to satisfy itself that it is in the public interest to do so, it is still necessary to obtain the approval of the Lieutenant Governor in Council. ${ }^{39}$

The permit will be for a prescribed term and will set out the pool, field or area from which the permittee may remove the gas or propane, the annual quantities and the maximum quantity to be removed from each such pool, field or area. The permit will likely require the permittee to supply gas or propane at a reasonable price to Alberta communities who desire it and who satisfy the Board that they can reasonably be supplied by the permittee. ${ }^{ \pm 0}$

The Board may, with the approval of the Lieutenant Governor in Council, at any time where an unforeseen emergency creates a reserve shortage for Alberta consumers, adjust the allowable production rates set forth in the permit or may divert the exportable product to other uses. ${ }^{41}$

The permit can be assigned only with the consent of the Board after approval of the Lieutenant Governor in Council. ${ }^{* 2}$ Where the Lieutenant Governor in Council so directs, or where the Board considers that circumstances require it, or on application of the permittee, the Board may hold a hearing to amend or reconsider a permit. ${ }^{43}$

Notwithstanding the foregoing, the Board, with approval of the Lieutenant Governor in Council, may grant, without a hearing but after publishing notice, an application for a permit authorizing the export from the Province of a total not to exceed one hundred billion cubic feet of gas or one million barrels of propane, where a recent published Board report shows ample surplus reserves in the Province to meet this export. ${ }^{44}$

There is a further qualification to the general requirements of the Act. Section 24 gives the Lieutenant Governor in Council, upon recommendation of the Board, the power to exclude from the application of the Act and upon such conditions as may be prescribed (1) any propane to be removed other than by pipeline, and (2) any propane to be removed by pipeline during a period not to exceed one year. Regulations pursuant to this section came into force on July $1,1965.45$ The regulations provide that propane may be removed from the Province in cylinder or bottle or by tank truck or tank car without complying with

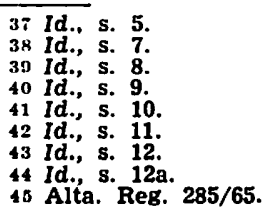


the provisions of the Act. ${ }^{40}$ An operator carrying on such an operation must make monthly reports of its exports ${ }^{4 i}$ and the Board may, at any time, with the approval of the Lieutenant Governor in Council, and if the Board is of the opinion that Alberta reserve demands for its local market are in danger, restrict such removal. ${ }^{48}$

The sections dealing with rules of practice, requirements for submission of evidence, and subpoena of witnesses, ${ }^{40}$ are similar to those contained in the Oil and Gas Conservation Act. ${ }^{50}$ There is a general statement that the Board, in performing the duties imposed on it by the Act, may exercise all the powers granted to it by the Oil and Gas Conservation Act to enable it to perform the duties imposed upon it by that Act. ${ }^{51}$ This provision greatly expands the powers of the Board and gives it the right, inter alia, to shut-in operations where waste is being committed. ${ }^{52}$

There is a general penalties section for any person who contravenes any provision of the Act or any permittee who, in conducting operations pursuant to his permit, violates any term thereof or any provision of the Act, and penalties are set forth for any such contravention or violation. ${ }^{\mathrm{s}}$ The Board is given the power to assess costs as between the applicant and any intervener or other party with a declared interest in a proceeding before the Board. ${ }^{54}$

The discretionary powers of the Board with respect to the hearing on an application for removal of gas from the Province are contained in section $8(3)$ which provides as follows:

The Board shall not grant a permit for the removal of any gas or propane from

the Province unless in its opinion it is in the public interest to do so having regard to

(a) the present and future needs of persons within the Province, and

(b) the established reserves and the trends in growth and discovery of reserves of gas or propane in the Province.

The procedures of the Board in interpreting this provision are of selfevident importance to gas producers. The term, "the present and future needs of persons within the Province" is an exceedingly general one, and the Board has adopted the practice of proceeding on the basis that this test will be met if the projected annual and peak day requirements of Alberta consumers, both domestic and commercial, are protected for a thirty-year period. Although the Dinning Commission in its report to the Government of Alberta, which lead to the passage of the Gas Resources Preservation Act, did some speculating as to the future gas reserve appreciation required to meet the future requirements of the Province for the next fifty years, ${ }^{55}$ it appears that Board policy as to a thirty-year provincial requirement was first enunciated at its initial hearing under the new Act on December 12, 1949. This was an application by Westcoast Transmission Company (Alberta) Limited to export Alberta gas to British Columbia, Washington and Oregon. ${ }^{56}$

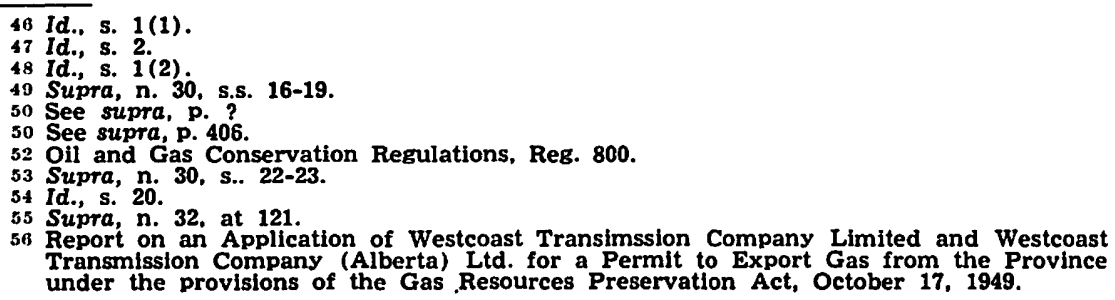


The determination of the Province's future requirements necessitates detailed economic studies based on projected population and industrial expansion within the Province. This area of evidence is not usually one in which the gas producing companies or the Canadian Petroleum Association, representing the gas industry, consider themselves competent insofar as the presentation of expert evidence is concerned. It is primarily in the matter of the supply of gas reserves that they can contribute valuable and reliable evidence essential to the Board's determination of whether a supply of gas exists, surplus to the needs of Alberta.

The procedure followed by the Board in determining whether such a surplus exists is somewhat complicated and must be thoroughly understood before one can make any qualified judgment as to whether gas producers are being treated fairly and equitably. This will be particularly important should the day come, as it inevitably must, when contractable reserves of gas are withheld from sale to available purchasers outside Alberta in order to protect the future needs of Albertans.

In examining the Board's procedure it is proposed to make reference to the Board's findings as set forth in its Report of October, 1967, relative to applications by Trans-Canada Pipe Lines Limited and Alberta and Southern Co. Ltd. and to use the reserves and requirements figures set forth in that Report. ${ }^{5 i}$ The first step taken by the Board is to determine the volume of remaining established reserves of marketable gas in the Province at the commencement of the period under consideration. ${ }^{58}$ Established reserves as defined by the Board are "the reserves of gas whose existence and estimated amount can reasonably be counted upon. They include all of the proved reserves and a judgment portion (usually 50 per cent) of the probable reserves." "s9 Proved reserves and probable reserves are defined as follows:

Proved reserves are the recoverable gas reserves within the area of a pool completely delineated by drilled wells. A portion of such reserves may be in drilling spacing units undrilled but so related to wells that there is every reasonable probability that the reserves will be produced either by the wells or by wells to be drilled on the drilling spacing units.

Probable reserves are the reserves of gas estimated to be recoverable from the pool beyond the proved limits of the pool. The probable pool limits are based on normal geological expectation. ${ }^{60}$

As at May 31, 1967, remaining established reserves were determined to be 39.3 trillion cubic feet or the equivalent of 41.9 trillion cubic feet of 1000 BTU gas. From this figure the Board deducted those reserves which were considered to be beyond economic reach, amounting to 2.9 trillion cubic feet and those reserves, amounting to 4.9 trillion cubic feet, the production of which would be deferred (due to cycling operations or their existence as an oil pool gas cap), leaving a contractable reserve figure of 34.1 trillion cubic feet of 1000 BTU gas. ${ }^{61}$ Of the 4.9 trillion cubic feet of deferred gas, the Board considered that 4.3 trillion would be available within thirty years and of the 2.9 trillion beyond economic reach, 1.8 trillion would be available within the thirty-year period. ${ }^{62}$

A further potential source of supply to be determined by the Board

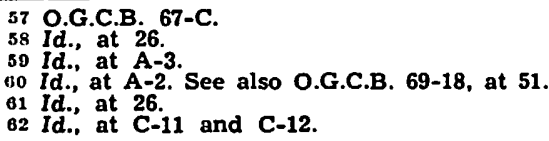


is trend gas. Trends in the growth of reserves over the past number of years due to new discoveries and appreciation of previous discoveries are determined and the long-term yearly average is calculated. The longterm average over the past sixteen years has been 2.5 trillion cubic feet per year. This figure is then compared with the yearly average over the most recent two years. Unless the two-year average is less than the long-term average, two years of trend gas based on the long-term average is added to the supply side of the ledger. In the Board's October, 1967, Report a total of 5.0 trillion cubic feet of trend gas was allowed since short term discovery and appreciation of reserve averages slightly exceeded the long-term average. ${ }^{63}$

The Board's next task is to determine the present and future requirements of gas in Alberta. As at May 31, 1967, the future thirty-year requirements were estimated at 12.4 trillion cubic feet with a peak day requirement in the thirtieth year of 2.7 billion cubic feet. ${ }^{i 4}$ To meet this demand the Board estimated that some 17.6 trillion cubic feet of reserves would be required. Of this figure, 5.2 trillion cubic feet would be required to meet the thirtieth year peak day. ${ }^{05}$ Board policy dictates that of the total provincial requirements, contractable requirements must be the greater of thirty times the current annual requirement or the remaining reserves in those fields connected to and supplying Alberta requirements. Thirty times the current annual requirement amounted to 6.4 trillion cubic feet, whereas remaining reserves in fields connected to Alberta requirements amounted to 6.5 trillion cubic feet. ${ }^{\text {on }}$ Therefore, of the total figure of 17.6 trillion cubic feet, 6.5 trillion cubic feet will be satisfied by reserves already under contract to supply Alberta needs, leaving 11.1 trillion cubic feet as a measure of the reserves necessary to meet remaining requirements not now under contract or connected to the Alberta market. ${ }^{67}$

The contractable reserve requirement necessary to meet remaining commitments on previously approved permits is then calculated and at May 31, 1967, this figure was 24.3 trillion cubic feet, including 0.8 trillion cubic feet to ensure deliverability in the terminal year of these permits. By adding the figures of 24.3 to the 6.5 trillion cubic feet of reserves under contract to Alberta consumers, the Board arrived at a total existing contractable reserve commitment of 30.4 trillion cubic feet. Referring back to our initial calculation of contractable reserves of 34.1 trillion cubic feet, it becomes apparent that the contractable surplus is 3.3 trillion cubic feet. ${ }^{\text {in }}$

The moment of truth becomes imminent. Will this contractable surplus be made available for removal from Alberta or must it be "locked in" to guarantee the future needs of Albertans?

The future needs of Albertans not covered by already contracted reserves was 11.1 trillion cubic feet. By adding to trend gas of 5.0 trillion cubic feet, deferred production of 4.3 trillion cubic feet and gas presently beyond economic reach but which can be produced within thirty years amounting to 1.8 trillion cubic feet, a total of 11.1 trillion

\footnotetext{
i.3 Id.; at 27

is Ibid.

6.: Id., at 28.

Gi) Id., at C-4.

68 Id., at 28-29.
} 
cubic feet is obtained, assuring Albertans, from these combined sources, the protection of their future requirements which the Act guarantees. The contractable surplus is therefore available for removal to markets outside the Province.

It is readily apparent that had the total future requirements of the Province of Alberta been projected to any quantity in excess of 17.6 trillion cubic feet or had the thirty year contractable requirements of Alberta exceeded the figure of 6.5 trillion cubic feet of contractable reserves already committed to the Alberta consumer, export would not have been permitted of that portion of the available 3.3 trillion cubic feet of surplus contractable reserves, equivalent to such excess. ${ }^{69}$ In anticipation of such a situation developing, the Canadian Petroleum Association has been advocating

(a) the use of probable, as opposed to established, reserves in the calculation of the contractable surplus, and

(b) the use of a minimum of five years, as opposed to two years, trend gas in the calculation of the future and overall surpluses.

The Association defines "probable reserves" as a realistic estimate of the reserves that will ultimately be recovered from known pools. In advocating the use of probable reserves, the Association contends that the Board's present reliance on established reserves gives inadequate recognition to the appreciation of existing reservoirs consequent on development drilling. It is also contended that only some $40 \%$ of the Board's estimate of trend gas relates to new discoveries, the remaining $60 \%$ representing appreciation of existing reservoirs. As a consequence of its recommendations, the Association would re-define trend gas to include only new discoveries and the appreciation relating thereto. The recommendations of the Association were not accepted by the Board. In the application under consideration the Board was no doubt justified in contending that an unnecessary and burdensome amount of gas would not have to be shut-in to meet the future requirements of Alberta. However, the Board did accept the Association's argument that reserves not yet known but which could reasonably be counted upon should be used to determine surplus. The Board believed, nevertheless, that its current policy of using reserves equivalent to two years' growth should continue unchanged. It is apparent that when the day comes that contractable reserves must be "locked in" to protect future Alberta requirements, the Board and the Industry will both be confronted with the effect of such a situation on the incentive for continued gas exploration in the Province. It is the continuance of this incentive which the Industry considers to be the best guarantee for assuring future Alberta requirements.

\section{THE GAS UTILITIES ACT:0}

The Gas Utilities Board was constituted in amendments to the Gas Utilities Act in 1962. ${ }^{i 1}$ The Act provides that the Board shall be composed of the chairman of the Public Utilities Board, the chairman of the Oil and Gas Conservation Board, or a member of each of those boards nominated by the respective chairman, and one member to be appointed 
by the Lieutenant-Governor-in-Council who shall be chairman. ${ }^{72}$ The present members of the Board are His Honour Judge Bruce C. Whittaker, Chairman; W. Nobbs, Chairman of the Public Utilities Board and Dr. G. W. Govier, Chairman of the Oil and Gas Conservation Board.

Matters to be heard by the Gas Utilities Board are set forth in section $49 b$ (1) of the Gas Utilities Act which reads as follows:

(1) Where the Public Utilities Board or the Oil and Gas Conservation Board is of the opinion that any application or matter before it

(a) may affect directly or indirectly the present or future supply of gas for domestic, commercial or industrial purposes within the Province, or the price or conditions under which such gas is supplied, or

(b) having regard to the availability of any other source or supply of gas, to the requirements of users of gas in any part of the Province and to any other circumstances,

may affect a public interest, and considers that the application or matter may involve or affect a matter that is wholly or partly within the jurisdiction of the other board, it may of its own motion or on request of any person who may be affected, refer the application or matter to the Gas Utilities Board and notwithstanding any other provisions of this Act or the Oil and Gas Conservation Act, the Gas Utilities Board may grant or refuse the application or make such disposition of the application or matter as it deems proper.

This section does not apply to an application or matter under The Gas Resources Preservation Act, 1956. ${ }^{i 3}$ From Section $49(1)$ it is noted that a public interest requires the assurance of the present or future supply of gas for domestic, commercial or industrial purposes in Alberta and that the supply is available at a fair and reasonable price and on similar conditions. Export of gas would not be permitted if it interferes with these terms. The Board may make any order that could be made by the Public Utilities Board under the Gas Utilities Act or the Oil and Gas Conservation Board under the Oil and Gas Conservation Act or with the approval of the Lieutenant-Governor-in-Council, such orders as aforesaid requiring such approval. The Board is also empowered to make such further orders and impose such additional conditions as it considers necessary in the public interest. ${ }^{i t}$

Upon a question of jurisdiction or upon a question of law, an appeal lies from the Board to the Appellate Division of the Alberta Supreme Court. $^{\text {is }}$ Subject to these rights of appeal, every decision or order of the Board is final and no order, decision or proceeding of the Board shall be subject to prohibition, injunction, certiorari, or any other court process or proceeding. ${ }^{\text {ic }}$

While the matter of conservation is of prime importance a key phrase in the jurisdiction of the Board is the "public interest." While public interest is not defined in the Act it has been the subject of extensive interpretation by counsel who have appeared before the Board on behalf of applicants and interveners. In general terms it has been said to be the greatest good for the greatest number within Alberta, of general interest, general economic interest to all Albertans-and to include something in which the community at large has an interest or which may affect the Province as a whole.

The public interest in relation to gas is expressed in various pieces

\footnotetext{
72 Id., 8. $49 \mathrm{a}(1)$.

73 Id., s. $49 b(2)$

74 Id., s. $49 \mathrm{~b}(3)$.

75 Id., s. $49 \mathrm{~d}$.

76 Id, $8,49 \mathrm{e}$
} 
of legislation in Alberta, for example, the Oil and Gas Conservation Act (to effect conservation, prevent waste and allow each owner to obtain his just and equitable share of production from a pool); the Gas Resources Preservation Act (to preserve and conserve Alberta gas and to provide for its effective use for present and future need of Albertans); the Alberta Gas Trunk Line Company Act ${ }^{i-}$ (creating a gas trunk grid system to transport gas and make it available within Alberta) and the Gas Utilities Act (to ensure that a fair and reasonable price will be paid or charged for gas in Alberta). These Acts and regulations under them are administered under stated Alberta Government policies made in the public interest, such as the export of gas which is surplus to Alberta's 30-year requirements, and encouragement of exploration and development of oil and gas resources to maintain and increase the level of economic activity in the Province.

The public interest appears to comprise several interests including individual and private interests. Thus there is the interest of the producer who is entitled to a fair price and profit under our free enterprise economy, and the interests of the consumer of the gas who should receive it at a "fair" price bearing in mind the economics of supply and demand. The Board agreed with a submission to it "that it is in the public interest, that manufacturing establishments and secondary industries should be encouraged to locate in Alberta and that those who do locate here should be encouraged to remain and if possible to expand.": However, the Board added that this "encouragement" should not be at the expense of the oil and gas producing industry or of other consumers of gas. ${ }^{79}$ It is the onerous duty of the Board to consider these various interests and bearing in mind the public interest, to reach a decision.

In its decision of June 8,1962 , in the matter of the applications of Imperial Oil Limited, Federated Processing Ltd. and Canadian Industrial Gas Limited for approval of schemes for the gathering, processing and disposal of gas in the Swan Hills and surrounding areas the Board said with respect to the public interest:

As the Board sees it, the public interest includes the private and individual interests of the producers, of the domestic, commercial and industrial consumers in Alberta and in the Edmonton area in particular, of the petrochemical industry, and of the utility companies. Also included are the broad and general interests of the people of the Province, which involves the impact on business climate and the like. ${ }^{80}$

There are no published rules of practice and procedure for the Gas Utilities Board or provision for them in the Gas Utilities Act although these are provided in detail for the Oil and Gas Conservation Board and the Public Utilities Board. However, the practice appears to be similar. Based upon the transcript of the original hearing of the Board ${ }^{\mathrm{N}}$ the procedure appears as follows. At the hearing the reference from the Oil and Gas Conservation Board or the Public Utilities Board is read and filed as an exhibit as is the notice of the hearing in the press and

77 S.A. 1954 , c. 37.

8ecision of the Gas Utilities Board in the Matter of Applications by Imperial Oil Limited, Federated Processing Ltd. and Canadian Industrial Gas Limited for approval of a scheme for the gathering, processing and disposal of gas produced in the Judy 78 Ibid.

so Id., at 2.

81 Supra, n. 78. 
to counsel for the applicants and interveners at the hearing before the Oil and Gas Conservation Board or the Public Utilities Board. The chairman then requests the appearances which are recorded. Following this, the chairman announces the manner in which it is proposed to proceed with certain procedural matters. For example, that the Board proposes to adopt as part of the record the record of the hearings of the Oil and Gas Conservation Board or the Public Utilities Board with respect to the original applications and that applicant will be heard first, followed by the interveners in the order registered, with applicants to make submissions as a result of the interventions and brief closing oral argument. Counsel are asked to speak to these. After hearing counsel, the Board then states the procedure to be followed. Each party calls its witnesses who are examined in chief and are subject to cross-examination by the Board and counsel for interested parties. Each counsel is allowed to give oral argument with those representing the interveners going first, followed by counsel for the applicants and the Board. Decision is usually reserved for later presentation. 